\title{
Prince Ahmose Sapair again
}

\author{
Cristina PINO FERNÁNDEZ
}

\begin{abstract}
Some years ago, I argued in an article published in this journal that the figure being worshipped on British Museum stela BM 360 is Prince Ahmose Sapair. Claude Vandersleyen indicates serious doubts about this identification in a recent book. My aim in these few lines is to refute his arguments against the identity of Ahmose Sapair in the above mentioned stela.

Hace unos pocos años, defendí en un artículo publicado en esta misma revista que la persona venerada en la estela BM 360 del British Museum es el príncipe Ahmose Sapair. Claude Vandersleyen ha mostrado serias dudas respecto a esta identificación en un libro reciente. Mi propósito en estas breves líneas es rechazar sus argumentos contra la identidad de Ahmose Sapair en la estela mencionada.
\end{abstract}

KeY Words: New Kingdom, XVIIIth Dynasty, Deir el-Medina, Ahmose Sapair, deification

$\mathrm{I}$ 2003, I published an article dealing with a very interesting artefact in the British Museum (BM 360), a stela on which Nakhy, a worker of Deir el-Medina, can be seen worshipping an image named in the accompanying text as "Satpair" who, in my opinion, is the "sanctified" prince Ahmose Sapair. ${ }^{1}$

Professor Vandersleyen has published research relating to this individual. His studies appeared first in an article some years $\mathrm{ago}^{2}$, and more recently in a book. ${ }^{3}$

Firstly, I wish to thank Vandersleyen for having read my work, despite the fact that he does not share my approach. Nevertheless, I do believe that his objections to my article lack the required precision and, for that reason, my aim in these few lines is simply to refute them.
During the period when I was working on stela BM 360 , only the first article was available. In it, Vandersleyen enumerates up to 20 documents related to Ahmose Sapair; this stela is not catalogued amongst them. I am at a loss to explain the reasons for this omission, because the author does not mention the piece at all. However, his recent book alludes frequently to BM 360 and twice illustrates it $^{4}$. In these pages, he writes:

doc. 16, (BM 360) donc l'association avec le prince n'est pas tout à fait sûre ${ }^{5}$.

Again, he states:

Reste une stèle où Satpaïr (sic) n'est que $m 3^{C}$ hrrw, sans autre épithète, ni titre, sans être associé à des personnages divinisés, la stèle BM EA $360($ doc. $16=C 11 a)[\ldots]$ Il pourrait s'agir du prince Iahmès Sapaïr mais il n'y a pas de certitude à se sujet. Par contre, quand on rencontre l'association

1. Pino, Cristina (2003): "British Museum stela BM 360”, TdE 2: 117-122.

2. Vandersleyen, Claude (1983): "L'identité d'Ahmès Sapaïr", SAK 10: 311-324.

3. Vandersleyen, Claude (2005): Iahmès Sapaïr, fils of Séqénenré Djéhouty-Aa (17e dynastie) et la statue du Musée du Louvre E 15682. (Connaissance de l'Égypte ancienne, 8). Bruxelles.

4. Vandersleyen, 2005: 30, 32, 33, 34, 37, 42, 48.

5. Vandersleyen, 2005: 32. 
exceptionnelle des deux noms, Iahmès et Sapaïr (doc. 12 et doc. $21=$ C15), même sans titre, on est en droit d'attribuer ces documents au prince . $^{6}$

And, finally, he alludes to my paper asserting that:

[the author] part de mauvaises bases, car, dans cette stèle, il n'est pas sûr que le personnage représenté soit le prince ${ }^{7}$.

When one reads these paragraphs, it is clear that Vandersleyen, at least, has reservations about the identity of the figure worshipped on BM 360, a fact which has even more significance with reference to my paper. Moreover, he does not give any credit to M. Bierbrier, whose opinion is transcribed in the book, who states:

The context of this stela is quite clear but has been badly misinterpreted in the past. Sitpair is in fact the deified Prince Ahmose Sipair who was the subject of a funerary cult after his death ${ }^{8}$.

In the same way, Vandersleyen disparages R. J. Demarée's assessment of BM 360 as he omits reference to Demarée's description of the stela:

On the left Sipair (doubtless Prince AhmoseSipair in view of the representation) ${ }^{9}$.

As indicated above, Vandersleyen argues against the identity as Ahmose Sapair in this stela basing his argument on several omissions: the name Ahmose, the title $s 3 n s w$ or other royal deified persons. Nevertheless, it is surprising that these omissions do not prevent the author from identifying as Prince Ahmose Sapair the blue glass statuette of the State Her[108 ] mitage Museum (Inventory number 752). As A. O. Bolshakov asserts:

A complexity of technology made glass statuettes a luxury and, probably, they were manufactured only in royal workshops; at least most of them represent kings ${ }^{10}$.

The inscription on the back of the throne only reveals: $s 3$ p3 ir $m 3^{\top}$ hrw , just as BM 360. No other written reference, no more than the possibility of being a royal person derived from the luxurious material, according to Bolshakov, or the conviction of being Ahmose Sapair as Vandersleyen affirms:

Cette statuette est un fac-similé en réduction de la statue de Louvre [...] l'image du prince a tellement frappé les esprits qu'on respectait même son apparence matérielle ${ }^{11}$.

In other words, we should accept the identity of the statuette simply because it resembles the one in the Louvre of Prince Ahmose, which Vandersleyen considers Ahmose Sapair. The complete name, the titles, the company of royal deified persons, appear to be no longer necessary, only the appearance: exactly the same argument used by Demarée referring to BM 360 .

On the other hand, although the author does not wholly admit the British Museum stela is dedicated to the deified prince, there seems to be no objection to its inclusion in the "Table succincte des attestations utilisées" 12 or to the identification of the theoretically doubtful figure on the left as "Le prince" in the "Liste des documents utilisés", number $16^{13}$. In my opinion, both uses of BM 360 are a flagrant contradiction to Vandersleyen's conclusion about the "mauvaises bases" of my paper.

Finally, I still consider, among all other arguments already expressed in my above mentioned article, that the stela BM 360 is "the first evidence of worship to Prince Ahmose Sapair in Deir el-Medina".

6. Vandersleyen, 2005: 33-34.

7. Vandersleyen, 2005: 34, note 108,

8. Bierbrier, Morris (1993): Hieroglyphic Texts from Egyptian Stelae. Part 9. London: 10, pl. 7.

9. Demarée, Robert Johannes (1983): The 3h i $\mathrm{kr} n \mathrm{r}^{\mathrm{C}}$-Stelae. On Ancestor Worship in Ancient Egypt. Leiden: 168.

10. Andrey O. Bolshakov. The Global Egyptian Museum. Directed by Dirk van der Plas and Mohamed Saleh. http://www.globalegyptianmuseum.org/detail.aspx?id=13767

11. Vandersleyen, 2005: 24.

12. Vandersleyen, 2005: 37.

13. Vandersleyen, 2005: 42. 


\section{Juan Antonio Belmonte}

Instituto de Astrofísica de Canarias

Vía Láctea $\mathrm{S} / \mathrm{N}$

38200 La Laguna, Tenerife - Islas Canarias

España

$$
\text { jba@iac.es }
$$

\section{Marcelo Campagno}

Instituto Multidisciplinario de Historia y Ciencias Humanas

Departamento de Egiptología

Saavedra $15,5^{\circ}$ piso

C1083ACA Buenos Aires

Argentina

mcampagno@fibertel.com.ar

\section{Lucía Elena Díaz-Iglesias Llanos}

Dpto. de Prehistoria, Antropología e Historia Antigua

Facultad de Geografía e Historia - Campus de Guajara

38071 Universidad de La Laguna

Tenerife - Islas Canarias

España

luch68@hotmail.com

\section{Magdi Fekri}

Faculty of Tourism

Minufiya University

El-Sadat City

Egypt

per-ankh@hotmail.com

\section{Cristina Pino Fernández}

cristinapino@telefonica.net 


\section{Mosalam Shaltout}

Helwan Observatory

Helwan, Cairo

Egypt

mosalamshaltout@hotmail.com

\section{Eric P. Uphill}

Institute of Archaeology

University of London

31-34 Gordon Square

London WC1H OPY

United Kingdom

\section{Marie-Paule Vanlathem}

Association Égyptologique Reine Élisabeth Musées Royaux d'Art et d'Histoire

Parc du Cinquantenaire 10

B-1000 Bruxelles

Belgique

mariepaule.vanlathem@belgacom.net 


\section{Trabajos de Egiptología}

\section{Papers on Ancient Egypt}

P

Número 4 2005 


\title{
Consejo Editorial
}

\author{
Miguel Á. Molinero Polo \\ Universidad de La Laguna \\ Antonio Pérez Largacha \\ Universidad de Castilla-La Mancha \\ José-R. Pérez-Accino \\ Birkbeck, Universidad de Londres \\ Covadonga Sevilla Cueva \\ Universidad Autónoma de Madrid
}

\section{Comité Científico}

Josep Cervelló i Autuori

Aula Aegyptiaca, Barcelona

Ma José López Grande

Universidad Autónoma de Madrid

Josep Padró i Parcerisa

Universitat de Barcelona

$\mathrm{M}^{\mathrm{a}}$ Carmen Pérez Die

Museo Arqueológico Nacional, Madrid

Ester Pons Mellado

Museo Arqueológico Nacional, Madrid

José M. Serrano Delgado

Universidad de Sevilla

\section{Colaboradores Editoriales}

Linda Steynor

English editorial assistant

Hervé Mouriacoux

Assistant editoriale pour langue française 
Juan Antonio Belmonte, Mosalam Shaltout, Magdi Fekri

Astronomy and landscape in Ancient Egypt:

Challenging the enigma of the minor step pyramids

\section{Marcelo Campagno}

Two observations on the tales of The contendings of Horus and Seth and Truth and Falsehood

\section{Lucía Elena Díaz-Iglesias Llanos}

Commentary on Heracleopolis Magna from the theological perspective (I):

The image of the local lakes in the vignette of chapter 17 of the Book of the Dead

Cristina Pino Fernández

Prince Ahmose Sapair again

Eric P. Uphill

Irrigation basins and cultivated land under the Twelfth Dynasty

\section{Marie-Paule Vanlathem}

Cléopâtre dans le miroir de la peinture du XIXe siècle 
Trabajos de Egiptología está producida por Isfet. Egiptología e Historia.

c/ Blanco $1,2^{\circ}$

38400 Puerto de la Cruz

Tenerife - Islas Canarias

España

Maquetación: Ignacio Cases

(C) Autores de los artículos aparecidos

y Consejo Editorial de Trabajos de Egiptología - Papers on ancient Egypt

Depósito legal:

ISSN 1695-4750

Impresión: 